\title{
Patrick Sachweh*
}

\section{Social Integration and Right-Wing Populist Voting in Germany}

\author{
How Subjective Social Marginalization \\ Affects Support for the AfD
}

https://doi.org/10.1515/auk-2020-0015

\begin{abstract}
Electoral support for right-wing populist parties is typically explained either by economic deprivation or cultural grievances. Attempting to bring economic and cultural explanations together, recent approaches have suggested to conceptualize right-wing populist support as a problem of social integration. Applying this perspective to the German case, this article investigates whether weak subjective social integration-or subjective social marginalization, respectively-is associated with the intention to vote for the AfD. Furthermore, it asks whether the strength of this association varies across income groups. Based on original survey data from 2017, the results show that indicators of weak subjective social integration-feeling socially excluded, being anxious about one's status, and distrusting others-increase the likelihood of voting for the AfD. Moreover, weak subjective social integration increases right-wing party support particularly among the middle-class. Thus, next to fears of downward mobility, feelings of subjective social marginalization emerge as a pathway to right-wing populism for the middle-class.
\end{abstract}

Keywords: exclusion, right-wing populism, social integration, voting behavior

\section{Introduction}

Since its formation in 2013, the right-wing populist party Alternative für Deutschland (AfD) has developed into the dominant far-right political force in Germany. In the last parliamentary election in 2017, 12.6 percent of the electorate have voted for the AfD, making it the largest opposition party in the German parliament. Originally

\footnotetext{
*Corresponding author: Patrick Sachweh, SOCIUM - Research Center on Inequality and Social Policy, Research Institute Social Cohesion (RISC), University of Bremen, Bremen, Germany, e-mail: sachweh@uni-bremen.de
} 
founded as a Eurosceptical platform by a group of conservative libertarians, since 2015 the AfD has increasingly adopted a populist stance focusing on issues of immigration, Islam and opposition to socio-cultural liberalism (Bieber et al. 2018; Lewandowsky et al. 2016). As a result, recent research shows that by now the AfD and its electorate closely resembles other right-wing populist parties in Europe (Arzheimer/Berning 2019). ${ }^{1}$ Thus, in comparison with the general population, men, the unemployed, people with lower levels of education, members of the working classes, and those with anti-immigrant and xenophobic attitudes are more likely to vote for right-wing populist parties (Golder 2016; Oesch 2008; Rydgren 2007).

Theoretically, contrasting explanations of right-wing populist party support exist. The 'losers of modernization'-perspective argues that support for right-wing populism is driven by economic grievances on the part of those disadvantaged by de-industrialization and globalization - that is, the lower-middle and working classes (Betz 1994; Minkenberg 2014). By contrast, the 'cultural backlash'-thesis views support for right-wing populism as a reaction against universalistic and postmaterialist values, and posits that a perceived threat to traditional social norms through immigration causes such cultural grievances (Inglehart/Norris 2017; Oesch 2008). These perspectives have often been juxtaposed as competing explanations for the recent resurgence of right-wing populism. Especially with regard to the German case, there has been some debate about whether support for the AfD can be accounted for by economic or cultural factors (Lengfeld 2017; Lengfeld/Dilger 2018; Lux 2018; Rippl/Seipel 2018; Sthamer 2018; Tutić/von Hermanni 2018). Yet, as anti-immigrant attitudes-and to some extent conservative-authoritarian values-are more pronounced among the lower-middle and working classes (Lipset 1959; Mewes/Mau 2012) and embedded in a context of profound societal transformations and rising inequality, both factors are interrelated and an integrative account seems warranted. Aiming to combine economic and cultural accounts, Gidron and Hall (2019) have recently proposed to understand support for populist parties as a problem of 'social integration'. They argue that "feelings of social marginalization can follow either from the loss of a valued economic position or from the perception that cultural elites no longer attach value to one's views" (Gidron/Hall 2019, 1031), and that it is the resulting discontent which underlies an alienation from mainstream politics and support for radical parties. While Gidron and Hall $(2017,2019)$ suggest that white working class men are especially affected by these developments, recent studies show that declines in subjective

\footnotetext{
1 The AfD can be defined as a right-wing populist party because of its ethno-nationalism, its authoritarian positions on socio-cultural issues, and its antiestablishment positions juxtaposing a "pure" people versus a “corrupt” elite (Rydgren 2007, 242-246)
} 
social integration extend into the middle classes as well (Engler/Weisstanner 2020; Kurer 2020). Hence, the degree to which feelings of marginalization matter more for some groups than others as a pathway to right-wing populism remains an open question.

This article adopts the framework proposed by Gidron and Hall (2019) and applies it to the German case. Specifically, I ask to what extent the intention to vote for the AfD is related to individuals' subjective social integration, or sense of marginalization, respectively. I draw on original survey data from 2017 which allow for an encompassing operationalization of subjective social integration. My empirical analyses investigate how three indicators for subjective social integration-social exclusion, status anxiety, and (dis)trust of others-are related to the intention to vote for the AfD. Furthermore, I investigate how these relationships differ across income groups. The results show that feeling socially marginalized increases the likelihood of intending to vote for the AfD, and that this effect is more pronounced in economically secure middle- and (partly) upper-income groups. This points out an incongruence between these groups' still dominant objective social position and their subjective assessment thereof. While these findings corroborate the overall fruitfulness of a social integration perspective on right-wing populism, they contrast with Gidron and Hall's (2019) suggestion that a subjective sense of social marginalization channels discontent especially among disadvantaged segments of the population. Thus, future research might further scrutinize group-specific effects of subjective social marginalization on right-wing populist support.

The paper is structured as follows. The next section (2) presents the core arguments of the losers of modernization- and cultural backlash-perspectives as well as relevant evidence regarding support for the AfD in Germany. Thereafter, the social integration perspective is presented as an integrative framework and specific hypothesis are derived. Section 3 presents the data and methods used, and section 4 presents the empirical findings. The last section (5) summarizes the findings and discusses avenues for future research. 


\section{Theoretical Perspectives on Right-Wing Populist Voting}

\subsection{Economic Grievances and the 'Losers of Modernization' Perspective}

The 'losers of modernization'-thesis identifies the transition from industrial to postindustrial economy as the root cause underlying electoral support for rightwing populist parties in Western countries (Betz 1994; Minkenberg 2014; Rydgren 2007, 248). ${ }^{2}$ It starts from the observation that processes of economic modernization-such as de-industrialization, tertiarization, and globalization-have profoundly transformed the labor markets of post-industrial societies, involving a liberalization, flexibilization, and deregulation of employment relationships (Blossfeld et al. 2011; Esping-Andersen 1993; Kalleberg 2009). At the same time, national welfare states underwent significant institutional changes, whereby social benefit levels have been lowered, eligibility rules tightened, and private responsibility for social provision strengthened (Gilbert 2002; Hacker 2004; Korpi 2003). Together, these changes contribute to a sense of heightened socio-economic insecurity and fears of social decline among citizens (Lengfeld/Hirschle 2009; Mau et al. 2012; Western et al. 2012). Importantly, however, the impact of these changes on social groups is uneven. The 'losers' of these developments are working-class members in manufacturing employment, the low-skilled, the unemployed, and the lowermiddle class (Rydgren 2007, 249). Consequently, income inequality in Western societies has increased since the beginning of the 21st century, with the working and lower-middle classes seeing stagnating or even shrinking income shares, while income gains have largely gone to the top of the distribution (Alvaredo et al. 2018; Milanovic 2016).

Why would modernization losers support right-wing populist parties? After all, right-wing populist parties often assume a market-liberal position with regard to economic issues that does not reflect the interests of disadvantaged groups (Kitschelt 1994). The literature discusses several mechanisms. First, voting for a right-wing populist party is viewed as a form of protest, reflecting the lower classes' disappointment with established parties' inability to cope with economic change

2 Various formulations of the 'losers of modernization'-perspective exist, with some versions also stressing not only economic but also socio-cultural transformations (e.g., Betz 1994). However, an encompassing review of these variants is beyond the scope of this paper (but see Spier 2010). More importantly, the German debate regarding support for the AfD tends to focus on modernization losers in the economic sense. 
and address their economic anxieties (Arzheimer 2008). Second, explanations based on realistic group conflict theory posit that the lower-middle and working classes compete with immigrants for scarce resources-e.g., low-skilled jobs, welfare benefits, or affordable housing-which resonates with the anti-immigrant and welfare chauvinistic positions of right-wing populist parties (Campell 1965). Third, processes of relative (or positional) deprivation are said to motivate the lower- and lower-middle classes' support for right-wing populism. These can involve unfavorable comparisons with past economic conditions (or negative future expectations), or with social reference groups that are perceived to be economically better-off (Burgoon et al. 2019; Runciman 1966).

With regard to the German AfD, empirical support for the losers of modernization-perspective is subject to some debate. Lengfeld (2017) finds that socioeconomically deprived groups-i.e., the working classes, low-income groups, the low-skilled or the unemployed-are no more likely than advantaged groups to state a voting intention for the AfD. Rather, persons with an average or above-average income appear slightly more likely to support the AfD (see also Bergmann et al. 2017; Lengfeld 2017, 223). However, other scholars have contended that the working classes, the low-skilled, and low-income groups are more likely to support the AfD (Lux 2018; Rippl/Seipel 2018; Tutić/von Hermanni 2018). Yet, the effects of objective indicators of socio-economic position are to some extent mediated by subjective experiences of deprivation and injustice (Lux 2018, 265; Tutić/von Hermanni 2018, 284). Accordingly, it has been proposed that, in line with the mechanism of relative deprivation, it is not objective socio-economic standing per se but the subjective perception of being relatively deprived-or the expectation of future decline-that matters for right-wing populist voting (Bergmann et al. 2017, 61; Kroh/Fetz 2016; Sthamer 2018). Along these lines, Sthamer (2018) shows that feelings of injustice, fear of downward mobility, and negative expectations about persistent intergenerational deprivation increase the probability to vote for the AfD, particularly among low- and middle-income groups (Sthamer 2018, 584-585).

In sum, the evidence in support for the losers of modernization-thesis with regard to the AfD suggests that the effects of objective indicators of socio-economic position appear to some extent to be mediated by subjective experiences of deprivation and insecurity.

\subsection{Cultural Grievances and the "Cultural Backlash'-Perspective}

In contrast, the 'cultural backlash'-perspective highlights long-term processes of socio-cultural transformation. Specifically, right-wing populist voting is largely 
seen as a "reaction against progressive cultural change" (Inglehart/Norris 2016, 2-3). This progressive change in values, or "silent revolution" (Inglehart 1971), has occurred from the 1970s onwards across Western industrial societies and was spurred by post-war birth cohorts experiencing unprecedented levels of existential security and affluence. Growing up under conditions of peace and prosperity has shifted their value priorities towards post-materialist values such as self-realization, environmental protection, human rights, gender equality, sexual diversity, cosmopolitanism, and multiculturalism (Inglehart/Norris 2016, 3; 2017, 444). It has supported the emergence of new social movements and Green parties, thus transforming the party systems of Western countries (Inglehart 1971; Kitschelt 2011).

From its start, however, post-materialist value change has been accompanied by materialist and authoritarian reaction on the part of older and less secure segments of the populace who saw their hitherto dominant cultural position challenged (Inglehart and Norris 2017). As post-materialist issues were accorded increasing importance by a growing number of citizens and politicians alike, older, less-educated, and often male citizens holding traditional social values felt increasingly out of step with the changing socio-cultural climate, leading to feelings of "resentment, anger, and a sense of loss" (Inglehart and Norris 2016, 14). Thus, according to the cultural backlash-thesis, "[t]he proximate cause of the populist vote is anxiety that pervasive cultural changes and an influx of foreigners are eroding the cultural norms one knew since childhood" (Inglehart/Norris 2017, 446). Right-wing populist parties exploit the desire of older, less-educated individuals to defend their social identity by highlighting the assumed incompatibility of immigrants' norms and values with those of the majority (Golder 2016, 485). Hence, in many Western societies a socio-cultural cleavage between "cosmopolitans" and "communitarians" has currently emerged as a major axis of conflict between political parties and citizens. While the former support the opening of national borders and the cross-border flow of goods and people, the latter demand greater national sovereignty, border control, and the regulation of migration and global economic exchange (Kriesi et al. 2006; Zürn/de Wilde 2016).

Empirically, the cultural backlash-thesis has received widespread support, in particular with regard to issues of immigration. Golder $(2016,485)$ cites evidence from multiple studies that show that anti-immigrant attitudes are positively associated with support for right-wing populist parties. Following the immigration of more than one million refugees from Syria, Irak, and Afghanistan during the socalled 'refugee crisis' in 2015, the AfD heavily mobilized around issues of migration. Hence, anti-immigrant attitudes, opposition to refugees, and conservative ideology have been consistently shown to increase the probability of supporting the AfD (Arzheimer/Berning 2019; Bieber et al. 2018; Goerres et al. 2018; Lengfeld/Dilger 2018; Schröder 2018). Furthermore, studies also find that anti-immigrant attitudes 
and opposition to refugees mediate the impact of low socio-economic status, as individuals with disadvantaged socio-economic positions are more likely to hold nativist or xenophobic views (Lengfeld/Dilger 2018; Schröder 2018). Some scholars argue that, in line with realistic group-conflict theory, working-class opposition to immigrants could be spurred by competition for scarce resources (e.g., Lux 2018; Rippl/Seipel 2018). However, comparative research shows that while there is some support for this assertion, the greater part of working-class opposition to immigration appears to be culturally grounded, i.e. rooted in the fear that immigrants would foster an erosion of national culture (Oesch 2008, 367). ${ }^{3}$

Yet, the fact that individuals in lower socio-economic positions support rightwing populist parties because they oppose post-materialist and multicultural values begs the question of whether economic and cultural accounts might be usefully combined. In fact, also Inglehart and Norris $(2016,16)$ suggest that economic insecurity and inequality may reinforce cultural shifts, but based on their empirical analyses, they ultimately conclude that "cultural values can provide the most useful explanation of European support for populist parties" (Inglehart/Norris 2016, 28).

\subsection{Social Integration-Combining Economic and Cultural Explanations}

Against the backdrop of this unsatisfactory-and somewhat artificial-bifurcation in the debate, Gidron and Hall (2019) have recently proposed to focus on 'social integration' as an integrative framework for understanding how both economic and cultural developments combine in fueling the discontent that underlies support for populist right-wing parties. Inspired by an ethnographic and qualitative literature that studies in-depth the social groups and regions most susceptible to right-wing populist appeals (e.g., Cramer 2016; Eribon 2016; Hochschild 2016), they foreground how experiences of being 'left behind' act as a catalyst for rightwing populist attitudes. Resulting from both economic and cultural shifts, such experiences involve a sense of 'social marginalization', i.e. of being "relegated to vulnerable economic and social positions, increasingly alienated from the values

3 As Oesch 2012 elaborates, "the radical right's mobilization of production workers could only meet with large success because other collective identities rooted in working-class culture or religion had become less relevant. As working-class organizations were weakened by deindustrialization and mass unemployment, other collective identities such as belonging to the national community could become salient among workers.” (Oesch 2012, 35) 
prominent in elite discourse, and lacking the respect accorded full members of society" (Gidron/Hall 2019, 1030).

Importantly, such an integrative framework captures essential elements of the 'losers of modernization'- and 'cultural backlash'-perspectives. It discusses how feelings of social marginalization are triggered by economic dynamics of de-industrialization and skill-biased technological change, which lead to a loss of low-skilled decent jobs and thus put the economic position of people without tertiary education at risk. Thus, greater insecurity and stagnating real-incomes in the lower third of the distribution might trigger perceptions of relative deprivation (Gidron/Hall 2017, S63; 2019, 1032). Parallel to that, cultural shifts have taken place that put greater emphasis not just on hard (manual) work, but on skills and entpreneurialism. Additionally, the promotion of gender equality, multiculturalism, and sexual diversity challenges social norms emphasizing hierarchical gender relations, ethnic homogeneity, and traditional sexual morality (Gidron/Hall 2017, S64; 2019, 1032). Particularly, these developments are said to challenge the social identity of older white men in the working- and lower-middle classes, whose economic sources of status become increasingly insecure (Gidron/Hall 2017, S77; 2019, 1048).

Taken together, economic and cultural dynamics may engender a larger syndrome of social marginalization, especially among the bottom third of the social hierarchy. Drawing on the sociological writings of Durkheim (1893/1997) and Blau (1965), Gidron and Hall (2019) conceptualize 'social integration' as a state-of-affairs which is said to obtain when people have access to meaningful work and feel that they are part of a community with shared normative values and beliefs in which they are treated as peers (Gidron/Hall 2019, 1030). Thus, the idea of social integration-and its counterpart, social marginalization-is able to integrate issues of relative deprivation, which are important in the losers of modernizationperspective, as well as concerns with social identity, which matter in the cultural backlash account. Gidron and Hall $(2019,1031)$ define social integration as a 'multidimensional phenomenon' that encompasses shared norms, social interaction with others, and being met with respect or recognition by others. ${ }^{4}$

Empirically, however, they use a single indicator to operationalize social integration as a "synthetic concept" (Gidron/Hall 2019, 2031), namely people's assessment of their subjective social status-as distinct from their objective class

\footnotetext{
4 This conception of 'social integration' has normative connotations, as social integration is implicitly viewed as a 'good thing'. However, strong social integration among some groups can also go along with the exclusion of others (Elias/Scotson 1994/1965). A systematic, up-to-date review of this (and other) implications of the concept of social integration is beyond the scope of this paper (but see Münch 2001).
} 
location-on a ten-step social ladder. ${ }^{5}$ Thus, Gidron and Hall's conceptualization of social integration refers to individuals' subjective assessment of their overall standing in society, independent from their "objective" social-structural position (e.g., class, income). Yet, they find that lower levels of subjective social integration-understood as seeing oneself located towards the bottom of the social ladder-are more pronounced among low-income groups, especially in contexts with higher inequality (Gidron/Hall 2019). Thus, weak social integration coincides with being in a socio-economically disadvantaged social position. Furthermore, weak social integration goes along with greater political discontent, vote abstention, and voting for right-wing populist parties (Gidron/Hall 2019, 1048, cf. also Gidron/Hall 2017). Recently, Reidinger (2020) has provided evidence for Austria showing that weak social integration increases populist attitudes and populist party-support.

However, while Gidron and Hall have shown that individuals in low socioeconomic positions report weaker subjective social integration (Gidron/Hall 2017), they do not analyze whether the effect of social integration-measured via subjective social status-on right-wing party support varies across different groups (Gidron/Hall 2019). Yet, recent studies have found that rising inequality increases support for right-wing populist parties especially among voters with high subjective social status and middle incomes, suggesting that fear of social decline might drive populist voting (Engler/Weisstanner 2020, 7, 15; cf. also Kurer 2020). This resonates with an argument put forward by German sociologist Theodor Geiger, who in an analysis of elections in the Weimar Republic of the 1930s has suggested that a 'fear of underestimation'-which could today be labeled 'status anxiety' (Wilkinson/Pickett 2010) ${ }^{6}$-had pushed the heterogeneous new middle-class of employees towards the NSDAP (Geiger 1930, 646). In sum, this suggests that among right-wing populist voters, a discrepancy between an objectively secure economic position and a subjective sense of weak social integration (or fear thereof) might exist. This, however, is inconsistent with Gidron and Hall's contention that feeling 'left behind' channels discontent especially among voters towards the bottom of the social hierarchy (Gidron/Hall 2019, 1032).

Based on these considerations and findings, I formulate the following hypotheses: First, I expect that lower levels of subjective social integration, or higher social marginalization, respectively, go along with a greater likelihood to vote for the AfD

5 While they show that subjective social status is related to three dimensions of social integration outlined above-being treated with respect, trust in other people, and participating in social activities and meetings (Gidron/Hall 2019, 1038), their analyses focus on the direct effect of subjective social status on populist attitudes.

6 In accordance with Wilkinson and Pickett (2010, 40), 'status anxiety' can be defined as an evaluative threat to individuals which involves being 'looked down upon' and 'feeling inferior'. 
(subjective marginalization hypothesis). In contrast to Gidron and Hall, I do not rely on the synthetic concept of subjective social status to operationalize social integration. Instead, I use three indicators that, in my view, capture important elements of their conception of social integration more directly: subjective social exclusion, status anxiety, and distrust of others. Importantly, these three dimensions refer to individuals' subjective sense of social integration, or marginalization, respectively. Thus, this operationalization allows for the possibility that social groups that appear well-integrated or privileged in an 'objective' sense-e.g., the middleand upper-income groups-might nevertheless express a subjective sense of social marginalization. Subjective social exclusion refers to the degree to which one feels as being part of society, whereas status anxiety refers to individual's subjective assessment of their social standing relative to others. Being (dis)trustful of others, finally, reflects in how far individuals feel as being part of a shared normative order or not. ${ }^{7}$

Furthermore, I investigate to what extent the effects of these indicators of social integration vary across different income groups. According to Gidron and Hall (2019), one would expect that subjective social marginalization goes along with an objectively deprived socio-economic position, thereby channeling discontent among voters in lower socio-economic positions. Hence, the effect of social integration should be more pronounced among low- (and lower-middle) income groups (left behind hypothesis). Following Geiger's reasoning, however, a sense of weaker subjective social integration might increase the probability of right-wing populist voting among objectively non-deprived middle-income groups, signaling a fear of potential social decline, and thus an incongruence between individuals' subjective marginalization and their objective socio-economic standing (social decline hypothesis).

\section{Data, Variables and Methods}

\subsection{Data}

The empirical analyses are based on original survey data that were collected within the context of a mixed-methods research project on 'Perceptions of Social Inequal-

\footnotetext{
7 I follow Godron/Hall $(2009,1038)$ in using generalized trust as an indicator for integration into the normative order, as one can assume that trusting others requires a belief that a minimum set of core values is also shared by others. For specific operationalizations, see section 3.2.
} 
ity and Justice in Germany'. ${ }^{8}$ The survey has been fielded between April and June 2017, and data have been collected by the commercial opinion research institute KANTAR public. The sample was drawn within a multi-stage random sampling framework and comprises a total of 2.089 German-speaking respondents, aged 18 years and above, who have been interviewed face-to-face (CAPI).

The questionnaire was developed on the basis of results from ten prior focus group discussions with different social groups across the full range of social hierarchy. In these focus groups, issues of socio-economic insecurity, social inclusion and exclusion, and recognition emerged as important topics to be covered in the standardized survey (next to questions about the perceived extent, reasons, fairness, and consequences of inequality). Participants from the focus groups, however, were not part of the standardized survey. The data offer a unique opportunity to operationalize different aspects of subjective social integration-or social marginalization, respectively-in greater depth than existing secondary data. Moreover, as the data are relatively recent, they are likely to reflect the right-wing turn of the AfD's electorate (Arzheimer/Berning 2019; Bieber et al. 2018). One potential limitation of the data is that after deleting cases with missing data on all of the variables used for analysis, the final sample is relatively small $(\mathrm{N}=917)$.

\subsection{Variables}

The core dependent variable is respondents' voting intention. This is measured via the so-called "Sunday question", which asks respondents whether they would cast a vote if a federal election were to be held next Sunday-and if so, which party they would vote for. ${ }^{9}$ As a substantial share of respondents states that they would not vote or do not know yet, the number of respondents that state an explicit party preference is 1.230 respondents. Furthermore, as voting in elections is socially selective, with individuals in low socio-economic positions being less likely to vote (Schäfer 2015), operationalizing right-wing populist voting with this item probably underestimates the share of potential voters for the AfD, especially as it has been relatively successful in mobilizing voters that were undecided in the last federal election. Furthermore, given that stating a right-wing populist party preference is socially undesirable, middle- and upper-class voters of the AfD might be underrepresented in the data. This drawback, however, is common to all survey-based methods of investigating right-wing populist voting. While analyzing city-, county-

8 This project has been conducted at Goethe-University Frankfurt from 2015 until 2018 and has received funding from the German Research Foundation (DFG, SA 2812/1-1).

9 Specific question wordings for all items can be found in Table A.1 in the appendix. 
or state-level election results might be an alternative approach which would not suffer from social desirability bias, these data would not offer any individual-level information about subjective social integration, or other individual characteristics of voters. Furthermore, one might consider to model not only party preferences but voting behavior more generally, for instance by including a third category of non-voters (and estimating either multinomial logit or Heckman selection models). Yet, as this would shift the research question in a slightly different direction, I focus explicitly on right-wing populist voting. I use a dummy coded variable indicating whether a respondent would intend to vote for the AfD (1) or not (0). A total of 77 respondents state a voting intention for the AfD, indicating that the distribution of this variable is rather skewed (cf. Table 1). ${ }^{10}$

To measure the different dimension of social integration, I use three independent variables. First, I use an indicator that measures respondents' subjective perception of their integration into society. This item asks respondents to indicate on a ten-point scale to what extent they feel integrated into society (10) or excluded (1). ${ }^{11}$ This variable is reverse coded, so that higher values indicate higher levels of social exclusion. Second, I utilize a composite index that measures status anxiety in order to assess whether individuals are anxious about their status and feel less respected or recognized by others. This index consists of three items: the first item asks whether respondents' feel that the value of what they do is not recognized, the second item asks whether they feel they did not achieve what they were hoping for, and the third item asks whether they feel that they get less than they deserve. Respondents were asked to indicate the degree to which they agree or disagree with these items on a five-point Likert-scale ( $1=$ totally agree, $5=$ totally disagree). These items are combined into an additive index (Cronbach's alpha $=0.68$ ), which was multiplied by 2 to harmonize scaling among the independent variables. Also, it was reverse-coded so higher values indicate higher levels of status anxiety. Third, I use generalized trust as an indicator for the sense of being part of a larger community with shared values. This item asks respondents to indicate whether they think that in general, most people can be trusted or not, with the response scale ranging from 1 ("most people cannot be trusted") to 10 ("most people can be trusted"). Also this item was reverse-coded so that higher values indicate lower levels of trust, or higher distrust, respectively.

Furthermore, I want to scrutinize whether the effects of these indicators of social integration vary across different income groups. Therefore, I interact them

10 This requires caution in the interpretation of interaction terms.

11 This item has been adapted from the panel study 'Labour Market and Social Security' (PASS), a survey designed by the Institute for Employment Research (IAB) in Germany for research on issues of labor market and poverty (Trappmann et al. 2013). 
with respondents' net equivalent household income, which is grouped into three categories: low incomes, when respondents have less than 70 percent of median net equivalent household income; medium incomes, for incomes between 70 and 150 percent of the median; and high incomes, for net equivalent household incomes above 150 percent of the median. Further control variables include education, which is classified into low, medium, and high education according to the CASMIN classification (Brauns et al. 2003). ${ }^{12}$ Also, I include a dummy variable for being unemployed, as the unemployed are more likely to support far-right parties. Age is recoded into four groups: 18-34 years old (respondents in the early phase of their occupational career), 35-49 years (respondents in an intensive work- and family phase), 50-64 years, (often occupationally secure respondents), and 65 years and above (usually retired respondents) (cf. Sthamer 2018, 575). I control for respondents' gender (1=female) and area of residence (1=East Germany), as men and East Germans are more likely to vote for the AfD.

\subsection{Methods}

In order to analyze how social integration relates to the intention to vote for the AfD, I first depict descriptively how the characteristics of AfD voters differ from those of the general population. Second, I use multivariate logit regression models to analyze how the three dimensions of social integration-social marginalization, status anxiety, and trust-are related to the intention to vote for the AfD. I first assess the impact of each indicator of social integration in a separate model that includes the control variables (M1-M4). Thereafter, I include interaction effects for income and social marginalization, status anxiety, and trust, respectively, in order to see whether the effects of social integration vary across income groups (M4-M6).

Because comparison of unstandardized logit coefficients across models is difficult in logistic regression (Long 1999), I present the results of the indicators for social integration from models M1-M4 in graphical form as predicted probabilities. Furthermore, to ensure comparability of models, Table A.2 in the appendix shows the average marginal effects (AME) for all variables in models M1-M4. These were calculated using the "margins" post-estimation command in Stata 15 (Williams 2012). I plot the interaction terms between the indicators for social integration

12 Low refers to an elementary level of education (with or without completed vocational training), medium to a secondary level of education (with or without completed vocational training, but without tertiary education), and high to a higher (tertiary) level of education (with lower- or upper-level certificates). 
and income graphically because an interpretation of interaction effects based on coefficients alone may be misleading in logistic regression (Ai/Norton 2003).

\section{Results}

\subsection{Descriptive results: Characteristics of AfD voters}

Tab. 1: Characteristics of AfD voters vs. overall sample

\begin{tabular}{lcc}
\hline & $\begin{array}{c}\text { AfD preference } \\
\text { share/mean }\end{array}$ & $\begin{array}{c}\text { Overall sample } \\
\text { share/mean }\end{array}$ \\
\hline Low income & 0.24 & 0.15 \\
Medium income & 0.60 & 0.61 \\
High income & 0.15 & 0.24 \\
Low education & 0.42 & 0.37 \\
Medium education & 0.51 & 0.41 \\
High education & 0.07 & 0.25 \\
Age 18-34 & 0.17 & 0.19 \\
Age 35-49 & 0.19 & 0.24 \\
Age 50-64 & 0.52 & 0.31 \\
Age 65 and above & 0.12 & 0.26 \\
Female & 0.34 & 0.48 \\
Unemployed & 0.11 & 0.03 \\
East Germany & 0.33 & 0.18 \\
Social exclusion & 5.02 & 3.17 \\
Status anxiety & 6.04 & 4.93 \\
Distrust & 6.24 & 5.08 \\
\hline $\mathrm{N}$ & 77 & 917 \\
\hline
\end{tabular}

Source: Survey “Perceptions of Inequality and Social Justice in Germany”, 2017

Table 1 depicts the characteristics of those who state a voting intention for the AfD, compared to the overall sample. Looking at different income groups, we see that respondents with low incomes are overrepresented among AfD voters in comparison to the overall sample ( 24 vs. 15 percent), whereas the share of persons 
with medium incomes is similar (60 vs. 61 percent) and high-income voters are underrepresented (15 vs. 24 percent). A similar picture emerges with regard to education: persons with low or medium levels of education are overrepresented among AfD voters (42 vs. 37 percent, and 51 vs. 41 percent, respectively), while the highly educated are underrepresented. With regard to age, we see that particularly middle-aged persons (35-49 years) are underrepresented among AfD voters (19 vs. 24 percent), whereas older persons below retirement age (50-64 years) are overrepresented (52 vs. 31 percent). Furthermore, women are underrepresented among AfD voters, while East Germans and the unemployed are overrepresented. These findings, especially with regard to income, education, and employment status, are in line with previous research and indicate that the 'losers of modernization' are somewhat overrepresented among AfD voters. The overall pattern indicates that the electorate of the AfD resembles that of other far-right parties in Europe (Arzheimer/Berning 2019; Bieber et al. 2018).

Looking at the indicators for social integration, we see that AfD voters-on average-report higher levels of social exclusion (mean value 5.02 vs. 3.17), show higher levels of status anxiety (6.04 vs. 4.93), and are more distrusting towards other people (6.24 vs. 5.08). These figures indicate that AfD voters appear to be less socially integrated than the overall sample. The following multivariate analyses investigate whether these findings persist once other relevant factors are controlled for.

\subsection{Multivariate Results: Social Integration and Right-Wing Populist Voting}

In the following, I will test the hypotheses formulated in the theoretical section. Table 2 presents the results of the multivariate logit regression models. After estimating a baseline model (M1) including income, education, employment status, age, gender, and region (East/West), models M2-M4 include the three indicators for social integration: subjective social exclusion, status anxiety, and (dis)trust. Their results shed light on the general role of social integration for right-wing populist voting intentions in Germany (subjective marginalization hypothesis). Thereafter, models M5-M7 additionally include interactions between income and social integration to scrutinize whether the effect of subjective social integration is more pronounced among low-income groups, as the left behind hypothesis in accordance with Gidron and Hall (2019) would suggest, or among middle-income groups, as the social decline hypothesis along the lines of Geiger (1930) and Engler and Weisstanner (2020) posit. 
Tab. 2: Logistic Regression of AfD Voting Intention on Social Integration

\begin{tabular}{|c|c|c|c|c|c|c|c|}
\hline & M1 & M2 & M3 & M4 & M5 & M6 & M7 \\
\hline \multicolumn{8}{|l|}{ Income (ref=low) } \\
\hline \multirow[t]{2}{*}{ middle } & -0.43 & -0.24 & -0.35 & -0.35 & -0.81 & -1.28 & -1.19 \\
\hline & $(0.45)$ & $(0.52)$ & $(0.46)$ & $(0.45)$ & $(0.82)$ & (1.29) & (1.26) \\
\hline \multirow[t]{2}{*}{ high } & -0.57 & -0.11 & -0.36 & -0.51 & -1.54 & $-2.39^{+}$ & 0.18 \\
\hline & $(0.60)$ & $(0.68)$ & $(0.63)$ & $(0.60)$ & $(1.16)$ & $(1.41)$ & (1.46) \\
\hline \multicolumn{8}{|l|}{$\begin{array}{l}\text { Education } \\
\text { (ref=low) }\end{array}$} \\
\hline \multirow[t]{2}{*}{ medium } & -0.08 & 0.20 & 0.04 & -0.05 & 0.20 & 0.02 & -0.11 \\
\hline & $(0.42)$ & $(0.42)$ & $(0.42)$ & $(0.41)$ & $(0.42)$ & $(0.42)$ & $(0.42)$ \\
\hline \multirow[t]{2}{*}{ high } & $-1.34^{*}$ & $-1.06^{+}$ & $-1.19^{+}$ & $-1.09^{+}$ & $-1.07^{+}$ & $-1.24^{+}$ & $-1.16^{+}$ \\
\hline & $(0.61)$ & $(0.61)$ & $(0.61)$ & $(0.64)$ & $(0.59)$ & $(0.65)$ & $(0.70)$ \\
\hline \multicolumn{8}{|l|}{ Age $(r e f=18-34)$} \\
\hline \multirow[t]{2}{*}{$35-49$} & -0.07 & 0.03 & 0.08 & -0.09 & -0.01 & 0.09 & -0.11 \\
\hline & $(0.50)$ & $(0.52)$ & $(0.48)$ & $(0.51)$ & $(0.51)$ & $(0.50)$ & $(0.52)$ \\
\hline \multirow[t]{2}{*}{$50-64$} & 0.70 & $0.84^{+}$ & $0.83^{+}$ & 0.69 & 0.81 & $0.86^{+}$ & 0.66 \\
\hline & $(0.51)$ & $(0.51)$ & $(0.49)$ & $(0.51)$ & $(0.51)$ & $(0.50)$ & $(0.51)$ \\
\hline \multirow[t]{2}{*}{$65+$} & -0.65 & -0.49 & -0.39 & -0.62 & -0.48 & -0.35 & -0.66 \\
\hline & $(0.57)$ & $(0.55)$ & $(0.54)$ & $(0.58)$ & $(0.55)$ & $(0.55)$ & $(0.58)$ \\
\hline \multirow[t]{2}{*}{ Female } & $-0.61^{+}$ & -0.39 & $-0.64^{+}$ & $-0.59^{+}$ & -0.42 & $-0.66^{+}$ & $-0.58^{+}$ \\
\hline & $(0.35)$ & $(0.35)$ & $(0.35)$ & $(0.34)$ & $(0.35)$ & $(0.35)$ & $(0.34)$ \\
\hline \multirow[t]{2}{*}{ Unemployed } & 0.85 & 0.28 & 0.52 & 0.66 & 0.57 & 0.80 & 0.73 \\
\hline & $(0.65)$ & $(0.72)$ & $(0.68)$ & $(0.69)$ & $(0.66)$ & $(0.62)$ & $(0.72)$ \\
\hline \multirow[t]{2}{*}{ East Germany } & $0.82^{\star *}$ & $0.77^{*}$ & $0.68^{*}$ & $0.82^{\star \star}$ & $0.75^{*}$ & $0.69^{*}$ & $0.82^{* *}$ \\
\hline & $(0.30)$ & $(0.32)$ & $(0.32)$ & $(0.30)$ & $(0.32)$ & $(0.32)$ & $(0.31)$ \\
\hline \multirow{2}{*}{$\begin{array}{l}\text { Subjective Social } \\
\text { Exclusion }\end{array}$} & & $0.30^{* \star *}$ & & & 0.18 & & \\
\hline & & $(0.07)$ & & & $(0.11)$ & & \\
\hline \multirow[t]{2}{*}{ Status Anxiety } & & & $0.20^{*}$ & & & 0.04 & \\
\hline & & & $(0.09)$ & & & $(0.16)$ & \\
\hline \multirow[t]{2}{*}{ Distrust } & & & & $0.22^{\star}$ & & & 0.15 \\
\hline & & & & $(0.09)$ & & & $(0.17)$ \\
\hline
\end{tabular}




\begin{tabular}{|c|c|c|c|c|c|c|c|}
\hline & M1 & M2 & M3 & M4 & M5 & M6 & M7 \\
\hline \multicolumn{8}{|l|}{ Interaction Effects } \\
\hline Middle income\# & & & & & 0.12 & & \\
\hline Exclusion & & & & & $(0.15)$ & & \\
\hline High Income\# & & & & & 0.34 & & \\
\hline Exclusion & & & & & $(0.24)$ & & \\
\hline Middle Income\# & & & & & & 0.15 & \\
\hline Status Anxiety & & & & & & $(0.20)$ & \\
\hline High Income \# & & & & & & $0.37^{+}$ & \\
\hline Status Anxiety & & & & & & $(0.22)$ & \\
\hline Middle Income\# & & & & & & & 0.14 \\
\hline Distrust & & & & & & & $(0.21)$ \\
\hline High Income \# & & & & & & & -0.13 \\
\hline Distrust & & & & & & & $(0.23)$ \\
\hline \multirow[t]{2}{*}{ Constant } & $-2.06^{* \star *}$ & $-3.78^{* \star *}$ & $-3.38^{\star \star \star}$ & $-3.36^{* * *}$ & $-3.15^{* \star *}$ & $-2.41^{*}$ & $-2.89^{\star \star}$ \\
\hline & $(0.54)$ & $(0.72)$ & $(0.73)$ & $(0.74)$ & $(0.75)$ & $(1.05)$ & $(1.08)$ \\
\hline Pseudo $R^{2}$ & 0.22 & 0.29 & 0.25 & 0.25 & 0.31 & 0.28 & 0.25 \\
\hline \multicolumn{8}{|l|}{ (McKelvey \& } \\
\hline \multicolumn{8}{|l|}{ Zavoina) } \\
\hline AIC & 448.94 & 423.73 & 443.02 & 439.29 & 424.31 & 444.61 & 440.56 \\
\hline $\mathrm{BIC}$ & 501.97 & 481.59 & 500.87 & 497.15 & 491.81 & 512.10 & 508.06 \\
\hline Log Likelihood & -213.47 & -199.87 & -209.51 & -207.65 & -198.16 & -208.30 & -206.28 \\
\hline $\mathrm{N}$ & 917.00 & 917.00 & 917.00 & 917.00 & 917.00 & 917.00 & 917.00 \\
\hline
\end{tabular}

Note: unstandardized logit coefficients, standard errors in parentheses, ${ }^{+} p<0.10,{ }^{*} p<0.05$, ${ }^{* *} p<0.01,{ }^{* *} p<0.001$, weighted data. Source: Survey "Perceptions of Inequality and Social Justice in Germany", 2017 
Looking at the results of the baseline model (M1), we see that persons with high levels of education are less likely to state a voting intention for the AfD, whereas East Germans are more likely to do so. Income, employment status, and age are not significantly associated with right-wing populist voting in a multivariate setting. Model M2 includes subjective social exclusion as a first indicator of subjective social integration-or social marginalization, respectively-and shows that the effect is statistically significant. Figure 1 depicts the predicted probabilities for right-wing populist voting across the values of social exclusion, showing that feeling socially excluded significantly increases the probability of voting for the AfD. This is in line with the subjective marginalization hypothesis. Furthermore, looking at the AIC and BIC values in Table 1, we see that including this indicator of social integration substantially improves model fit, which can also be seen in the increase of the Pseudo- $R^{2}$ (McKelvey \& Zavoina) from 0.22 to 0.29.

Fig. 1: Predicted Probabilities of Right-Wing Populist Voting and Social Integration
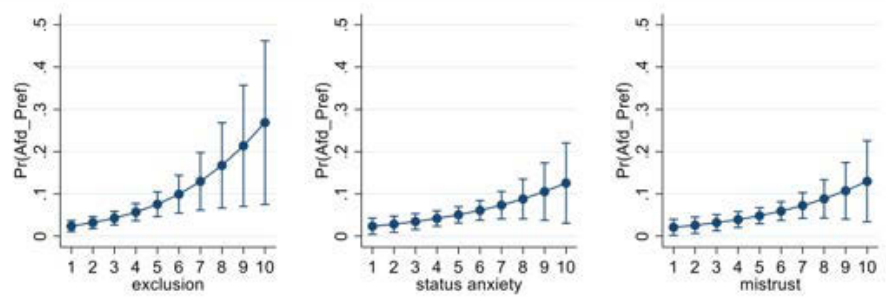

Note: Predicted probabilities of voting intention for the AfD across subjective social exclusion, status anxiety, and distrust towards others ( $95 \%$ confidence intervals); based on multivariate logit regression results in models M2-M4, other variables held at their means. $\mathrm{N}=917$

The second indicator for social integration, status anxiety, is included in model M3. This variable also significantly affects the likelihood of intending to vote for the AfD. Looking at the predicted probabilities in Figure 1, we find that higher values of status anxiety go along with a greater probability of intending to vote for the AfD, which again is in accord with the subjective marginalization hypothesis. In comparison to the effect of subjective social exclusion, the impact of status anxiety of right-wing populist voting appears to be smaller. In this model, there also is some improvement in model fit when compared to the baseline model, but the lower AIC and BIC values as well as the lower Pseudo- $\mathrm{R}^{2}(0.25)$ indicate that this improvement is smaller than in the case of M2. 
Model M4 includes distrust in others as a final indicator of subjective social integration, or social marginalization. Again, one can see that distrusting others significantly affects the intention to vote for the AfD. Figure 1 shows that higher values of distrust go along with a higher probability of right-wing populist voting, and its effect appears to be similar to that of status anxiety, but weaker than that of social exclusion. The improvement in model fit in M4 compared to M1 is stronger than in M3, but smaller than in M2, as can be seen from the AIC and BIC values.

In sum, the results from models M2-M4 provide evidence in support of the subjective marginalization hypothesis. Feeling socially excluded, being anxious about one's status, and being distrustful of others are associated with a greater probability of stating a voting intention for the AfD. These findings support Gidron and Hall's (2019) conceptualization of right-wing populist support as a problem of subjective social integration, or subjective marginalization, respectively.

Does the association of these indicators of social integration differ across income groups? To assess this, I now look at interaction effects between income and the indicators of social integration. Because the interpretation of interaction effects in non-linear models based on coefficients alone can be difficult or misleading (Ai/Norton 2003), I plot the significant interactions graphically. Figure 2 shows the average marginal effect (AME) of subjective social exclusion on the probability to vote for the AfD across income groups. While feeling socially excluded does not significantly affect right-wing populist voting intentions among low-income groups, it increases the probability to vote for the AfD among middleand high-income groups. This contrasts with the left behind-hypothesis formulated in accordance with Gidron and Hall (2019), and is principally in line with the social decline-hypothesis, which expected subjective social marginalization to affect support for right-wing populism especially among middle-income groups. This conclusion is further corroborated by the interaction between distrust in others and income, which is depicted in Figure 3. Here we see that being distrustful of others increases support for the AfD among the middle-class, but not among lowand high-income respondents. The effect of status anxiety (not shown here) does not differ significantly across income groups. 
Fig. 2: Subjective Social Exclusion, Income and Right-Wing Populist Voting

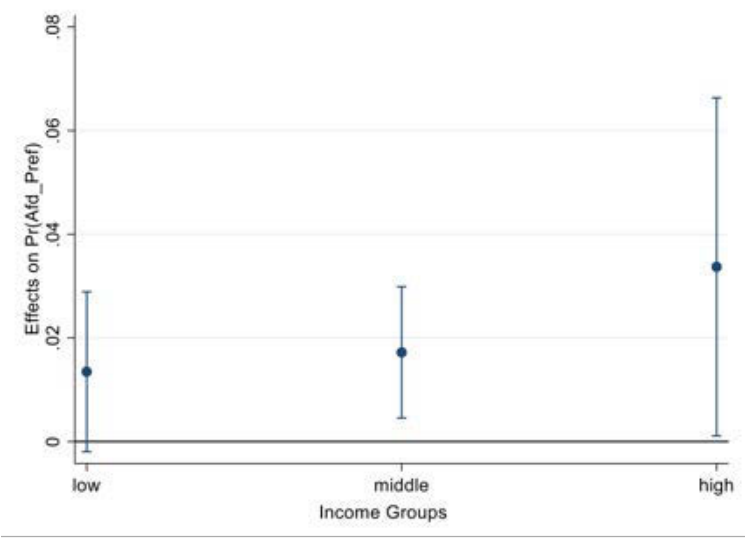

Note: Average marginal effects of interaction between subjective social exclusion and income on voting intention for the AfD (95\% confidence intervals); based on multivariate logit regression results in model $\mathrm{M} 5$, other variables held at their means. $\mathrm{N}=917$

Fig. 3: Distrust, Income and Right-Wing Populist Voting

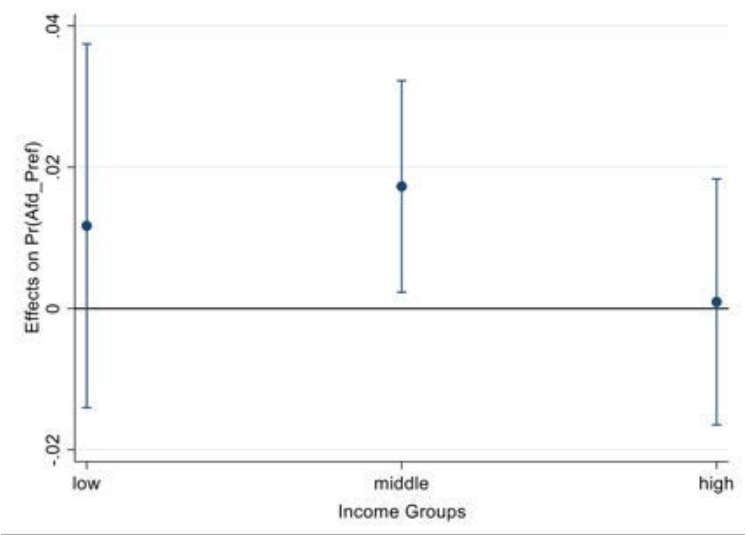

Note: Average marginal effects of interaction between distrust towards others and income on voting intention for the AfD ( $95 \%$ confidence intervals); based on multivariate logit regression results in model $\mathrm{M} 6$, other variables held at their means. $\mathrm{N}=917$ 
In sum, the findings from these interaction effects suggest that the association between weak subjective social integration and right-wing populist support is stronger among middle- and high-income groups than among low-income groups, for whom feeling socially marginalized does not make much of a difference in terms of voting intentions. This contrasts with Gidron and Hall's (2019) account of social marginalization as a sense of being 'left behind' that fuels discontent and populist sentiment especially among low (or lower-middle)-income groups. Instead, my findings suggest that a subjective sense of social marginalization-especially feeling socially excluded and being distrustful of others-has a greater impact among middle- and high-income groups which occupy socio-economically dominant or privileged positions. Thus, rather than reflecting a sense of being 'left behind' among the disadvantaged, a subjective sense of social marginalization might signal a discordance between middle- (and to some extent upper-)income groups and society as well, indicating that weak subjective social integration might act as an important pathway to right-wing populism for people in objectively secure socio-economic positions. Interestingly, there is no interaction effect between status anxiety and income, which would have provided the most direct evidence for a 'fear of social decline'-interpretation along the lines of Geiger (1930) and Engler and Weisstanner (2020). Hence, while my results are generally in line with studies pointing out the relevance of weak subjective social integration for rightwing populist support among the middle-classes (Kurer 2020; Engler/Weisstanner 2020), they do not fully support the interpretation that status anxiety-or fear of social decline-is driving right-wing populism among this group. What appears to characterize middle-class supporters of right-wing populism is not so much a fear of losing their dominant socio-economic position but rather a subjective sense of 'decoupling' between themselves and mainstream society, as evidenced in the effects of subjective social exclusion and distrust. Future research should look more closely into such-and similar-perceptions underlying right-wing populist support among the middle- (and upper-middle-)classes.

\section{Conclusion and Discussion}

This paper has followed a recent proposal by Gidron and Hall (2019) to conceptualize support for right-wing populism as a problem of social integration and applied this perspective to the German case. Specifically, I have investigated whether indicators of weak subjective social integration (or social marginalization, respectively) are associated with the intention to vote for the AfD, and whether the strength of this association varies across income groups. Based on original survey data that 
allow for a more direct operationalization of multiple dimensions of subjective social integration, the results show that feeling socially excluded, being anxious about one's status, and being distrustful towards others increase the likelihood to state a voting intention for the AfD. Moreover, subjective social exclusion and distrust increase right-wing party support particularly among the socio-economically dominant middle-income-and in the case of subjective exclusion, also among high-income-voters. These findings underscore the general usefulness of a social integration-perspective on right-wing populism.

Yet, my results also contrast with Gidron and Hall's (2019) conjecture that a sense of social marginalization channels political discontent especially among individuals in lower socio-economic positions. I find that a subjective sense of weak social integration, as indicated by feeling socially excluded and distrusting others, increases right-wing populist party support particularly among middle(and partly also high-)income groups. These findings are in line with recent comparative evidence (Engler/Weisstanner 2020) and suggest that feelings of social marginalization may provide an important pathway to right-wing populist party support among the middle-class. To some extent, this resonates with early interpretations of right-wing electoral behavior (Geiger 1930) as well as recent analyses (Engler/Weisstanner 2020) that emphasizes the middle-classes' susceptibility to right-wing appeals. However, while these analyses have highlighted the middleclasses' concern with status anxiety or a fear of social decline as mechanisms underlying their support for right-wing parties, the present analyses suggests that a broader sense of social marginalization-i.e., feeling excluded and distrustful of others-matters for this group as well. While other analyses have shown that fears of downward mobility do increase the probability to state a voting intention for the AfD among middle-income groups (Sthamer 2018), social marginalization might provide a further mechanism that reflects a sense of discordance between one's own position and the rest of society. Importantly, such feelings of social marginalization exist alongside the middle-classes' still dominant socio-economic position. Yet, as emphasized by the Thomas-Theorem (Thomas 1928), this subjectively perceived marginalization is highly consequential in generating support for a right-wing populist party among a social group that once was regarded as a safeguard of democratic stability. In any case, the findings of this article underscore the fruitfulness of the social integration perspective and encourage further research on the group-specific linkages between subjective social integration and populism.

Furthermore, while Gidron and Hall $(2017,2019)$ as well some other studies (Engler/Weisstanner 2020; Kurer 2020) have made use of subjective social status, future research might also look into alternative indicators to measure social integration on the individual level and test the validity of different measurements 
against one another. My results indicate that especially whether one feels socially excluded from or included into society could provide a suitable indicator that captures essential elements of subjective social integration, or social marginalization, respectively. Importantly, this indicator does not appear to reflect a narrowly defined perception of subjective socio-economic disadvantage but seems to indicate a broader sense of societal disaffiliation. Moreover, if the conceptualization of subjective social integration as a multidimensional phenomenon is going to be retained, I would encourage future efforts to also develop a multidimensional operationalization of social integration, as different aspects may be relevant for different social groups.

Finally, the results presented here are not without limitations. A first limitation is that due to restricted possibilities to operationalize anti-immigrant attitudes in the data used, I could not test how well the indicators for social integration perform relative to measures more directly reflecting the 'cultural backlash'-perspective. Additional analyses including one variable that appears at least somewhat suitable ${ }^{13}$ indicate that anti-immigrant sentiments continue to be significantly related to AfD support when subjective social integration is controlled for, though social marginalization still exerts a significant influence (cf. Table A.3 in the appendix). Yet, more research with different data for a variety of countries is needed to better disentangle the different effects of the cultural backlash- and social marginalization perspective.

A second, and somewhat related, limitation is that due to the cross-sectional nature of the data used here, no causal claims with regard to temporal ordering can be supported. As the aim of this paper was to explore the overall fruitfulness of the emerging social integration-perspective on right-wing populism for the German case against the backdrop of previous cross-sectional comparative evidence (Gidron/Hall 2019), this may not be a severe problem. Yet, as a social integration perspective indeed seems to provide a promising avenue for research on populism, future studies should use available longitudinal data to scrutinize on the individual level how processes of subjective disaffiliation channel into a sense of social marginalization, and how this in turn affects populist attitudes and right-wing party support.

13 This item asks respondents whether they agree with the statement that the "German government should spend its money for the native population rather than paying attention to specific groups (Banks, Greece, Refugees)". While this item, which has been formulated in response to results from the focus groups, taps into welfare chauvinist attitudes, it does not precisely measure genuinely cultural concerns about immigration. Furthermore, as its wording is somewhat close to AfD rhetoric, questions about endogeneity might be posed. 
In sum, the results of this paper underscore the fruitfulness of the social integration perspective for future research on populism, which may focus not only right-wing voting behavior but on populist attitudes and political disaffection more generally.

\section{References}

Ai, C./E. C. Norton (2003), Interaction Terms in Logit and Probit Models, in: Economics Letters 80, 123-129

Alvaredo, F./L. Chancel/T. Piketty/E. Saez/G. Zucman (2018), World Inequality Report. Retrieved from https://wir2018.wid.world/files/download/wir2018-full-report-english.pdf

Arzheimer, K. (2008), Die Wähler der extremen Rechten 1980-2002, Wiesbaden

Arzheimer, K./C. C. Berning (2019), How the Alternative for Germany (AfD) and Their Voters Veered to the Radical Right, 2013-2017, in: Electoral Studies 60

Bergmann, K./M. Diermeier/J. Niehues (2017), Die AfD: Eine Partei der sich ausgeliefert fühlenden Durchschnitts- verdiener?, in: Zeitschrift für Parlamentsfragen 48, 57-75

Betz, H.-G. (1994), Radical Right-Wing Populism in Western Europe, Houndsmills

Bieber, I./S. Roßteutscher/P. Scherer (2018), Die Metamorphosen der AfD-Wählerschaft: Von einer euroskeptischen Protestpartei zu einer (r)echten Alternative?, in: Politische Vierteljahresschrift 59, 433-461

Blau, P. M. (1965), A Theory of Social Integration, in: American Journal of Sociology 65, 545-556

Blossfeld, H.-P./S. Buchholz/D. Hofäcker/K. Kolb (2011), Globalized Labour Markets and Social Inequality in Europe

Brauns, S./S. Scherer/H. Steinmann (2003), The CASMIN Educational Classification in International Comparative Research. in J. Hoffmeyer-Zlotnik/C. Wolf (Eds.), Advances in CrossNational Comparison A European Working Book for Demographic and Socio-Economic Variables, New York, 221-244

Burgoon, B./S. van Noort/M. Rooduijn/G. Underhill/T. Beck (2019), Positional Deprivation and Support for Radical Right and Radical Left Parties, in: Economic Policy 34, 49-93

Campell, D. D. (1965), Ethnocentric and Other Altruistic Motives. in D. Levine (Ed.), Nebraska Symposium on Motivation, Lincoln, 283-311

Cramer, K. J. (2016), The Politics of Resentment: Rural Consciousness in Wisconsin and the Rise of Scott Walker, Chicago

Durkheim, E. (1893/1997), The Division of Labor in Society, New York

Elias, N./J. L. Scotson (1994/1965), The Established and the Outsiders. A Sociological Enquiry into Community Problems, London

Engler, S./D. Weisstanner (2020), The Threat of Social Decline: Income Inequality and Radical Right Support, in: Journal of European Public Policy, 1-21

Eribon, D. (2016), Rückkehr nach Reims, Berlin

Esping-Andersen, G. (1993), Changing Classes. Stratification And Mobility In Post-Industrial Societies, London

Geiger, T. (1930), Panik im Mittelstand, in: Die Arbeit 10, 637-654

Godron, N./P. A. Hall (2017), The Politics of Social Status: Economic and Cultural Roots of the Populist Right, in: British Journal of Sociology 68, Supplement 1, 57-S84 
- (2019), Populism as a Problem of Social Integration, in: Comparative Political Studies 53, 10271059

Gilbert, N. (2002), Transformation of the Welfare State, Oxford

Goerres, A./D. C. Spies/S. Kumlin (2018), The Electoral Supporter Base of the Alternative for Germany, in: Swiss Political Science Review 24, 246-269

Golder, M. (2016), Far Right Parties in Europe, in: Annual Review of Political Science 19, 477-497

Hacker, J. S. (2004), Privatizing Risk without Privatizing the Welfare State: The Hidden Politics of Social Policy Retrenchment in the United States. in: American Political Science Review 98, 243-260

Hochschild, A. R. (2016), Strangers in Their Own Land: Anger and Mourning on the American Right, New York

Inglehart, R. (1971), The Silent Revolution in Europe: Intergenerational Change in Post-Industrial Societies, in: American Political Science Review 65, 991-1017

Inglehart, R./P. Norris (2016), Trump, Brexit, and the Rise of Populism: Economic Have-Nots and Cultural Backlasch. Faculty Research Working Paper Series RWP16-026.

- (2017), Trump and the Populist Authoritarian Parties: The Silent Revolution in Reverse, in: Perspectives on Politics 15, 443-454

Kalleberg, A. L. (2009), Precarious Work, Insecure Workers: Employment Relations in Transition, in: American Sociological Review 74, 1-22

Kitschelt, H. P. (1994), The Radical Right in Western Europe. A Comparative Analysis, Ann Arbor

- (2011), Left-Libertarian Parties: Explaining Innovation in Competitive Party Systems, in: World Politics 40, 194-234

Korpi, W. (2003), Welfare-State Regress in Western Europe: Politics, Institutions, Globalization, and Europeanization, in: Annual Review of Sociology 29, 589-609

Kriesi, H./E. Grande/R. Lachat/M. Dolezal/S. Bornschier/T. Frey (2006), Globalization and the Transformation of the National Political Space: Six European Countries Compared, in: European Journal of Political Research 45, 921-956

Kroh, M./K. Fetz (2016), Das Profil der AfD-AnhängerInnen hat sich seit Gründung der Partei deutlich verändert, in: DIW Wochenbericht 34/2016, 711-719

Kurer, T. (2020), The Declining Middle: Occupational Change, Social Status, and the Populist Right, in: Comparative Political Studies 53, 1798-1835

Lengfeld, H. (2017), Die 'Alternative für Deutschland': eine Partei für Modernisierungsverlierer?, in: Kölner Zeitschrift für Soziologie und Sozialpsychologie 69, 209-232

- /C. Dilger (2018), Kulturelle und ökonomische Bedrohung. Eine Analyse der Ursachen der Parteiidentifikation mit der 'Alternative für Deutschland' mit dem Sozio-oekonomischen Panel 2016, in: Zeitschrift für Soziologie 47, 181-199

- ./J. Hirschle (2009), Die Angst der Mittelschicht vor dem sozialen Abstieg. Eine Längsschnittanalyse 1984-2007, in: Zeitschrift für Soziologie 38, 379-398

Lewandowsky, M./H. Giebler/A. Wagner (2016), Rechtspopulismus in Deutschland. Eine empirische Einordnung der Parteien zur Bundestagswahl 2013 unter besonderer Berücksichtigung der AfD, in: Politische Vierteljahresschrift 57, 247 - 275

Lipset, S. M. (1959), Democracy and Working-Class Authoritarianism, in: American Sociological Review 59, 482-501

Long, J. S. (1999), Regression Models for Categorical and Limited Dependent Variables, Thousand Oaks 
Lux, T. (2018), Die AfD und die unteren Statuslagen. Eine Forschungsnotiz zu Holger Lengfelds Studie Die 'Alternative für Deutschland': eine Partei für Modernisierungsverlierer?, in: Kölner Zeitschrift für Soziologie und Sozialpsychologie 70, 255-273

Mau, S./J. Mewes/N. M. Schöneck (2012), What Determines Subjective Socio-Economic Insecurity? Context and Class in Comparative Perspective, in: Socio-Economic Review 10, 655-682

Mewes, J./S. Mau (2012), Unraveling Working-Class Welfare Chauvinism. Welfare Attitudes in Europe and Beyond, in S. Svallfors (Ed.), Contested Welfare States, Stanford, 119-156

Milanovic, B. (2016), Global Inequality. A New Approach for the Age of Globalization, Cambridge Minkenberg, M. (2014), The Renewal of the Radical Right: Between Modernity and Anti-modernity, in: Government and Opposition 35, 170-188

Münch, R. (2001), Integration, social. in N. J. Smelser/P. B. Baltes (eds.), International Encyclopedia of the Social and Behavioral Sciences, Amsterdam, 7591-7596

Oesch, D. (2008), Explaining Workers' Support for Right-Wing Populist Parties in Western Europe: Evidence from Austria, Belgium, France, Norway, and Switzerland, in: International Political Science Review 29, 349-373

- (2012), The Class Basis of the Cleavage between the New Left and the Radical Right: an analysis for Austria, Denmark, Norway and Switzerland, in J. Rydrgen (ed.), Class Politics and the Radical Right, London, 31-51

Reidinger, V. (2020). Soziale Integration und Zuspruch für Populismus. Retrieved from https://viecer.univie.ac.at/corona-blog/corona-blog-beitraege/blog74/

Rippl, S./C. Seipel (2018), Modernisierungsverlierer, Cultural Backlash, Postdemokratie, in: Kölner Zeitschrift für Soziologie und Sozialpsychologie 70, 237-254

Runciman, W. G. (1966), Relative Deprivation and Social Justice. A Study of Attitudes to Social Inequality in Twentieth-Century England, London

Rydgren, J. (2007), The Sociology of the Radical Right, in: Annual Review of Sociology 33, 241-262

Schäfer, A. (2015), Der Verlust politischer Gleichheit. Warum die sinkende Wahlbeteiligung der Demokratie schadet, Frankfurt

Schröder, M. (2018), AfD-Anhänger sind nicht abgehängt, sondern ausländerfeindlich, in: SOEPpapers on Multidisciplinary Panel Data Research 975-2018

Spier, T. (2010), Modernisierungsverlierer, Wiesbaden

Sthamer, E. (2018), Die AfD-Wahl als Antwort auf Statusängste?, in: Zeitschrift für Sozialreform 64, 563-591

Thomas, W. I. (1928), The Methodology of Behavior Study, in The child in America: Behavior Problems and Programs, New York

Trappmann, M./J. Beste/A. Bethmann/G. Müller (2013), The PASS Panel Survey After Six Waves, in: Journal for Labour Market Research 46, 275-281

Tutić, A./H. von Hermanni (2018), Sozioökonomischer Status, Deprivation und die Affinität zur AfD - Eine Forschungsnotiz, in: KZfSS Kölner Zeitschrift für Soziologie und Sozialpsychologie $70,275-294$

Western, B./D. Bloome/B. Sosnaud/L. Tach (2012), Economic Insecurity and Social Stratification, in: Annual Review of Sociology 38, 341-359

Wilkinson, R./K. Pickett (2010), The Spirit Level. Why Greater Equality Makes Societies Stronger, New York

Williams, R. (2012), Using the Margins Command to Estimate and Interpret Adjusted Predictions and Marginal Effects, in: Stata Journal 12, 308-331

Zürn, M./P. de Wilde (2016), Debating Globalization: Cosmopolitanism and Communitarianism as Political Ideologies, in: Journal of Political Ideologies 21, 280-301 


\section{Appendix A}

Table A. 1: Question Wording for Dependent Variables

\section{English}

Subjective Social Exclusion

Status Anxiety (additive index)

(Dis)Trust
"One may either feel like participating in social life and like being integrated into society or one may rather feel excluded. How about you? To what extent do you feel integrated or do you rather feel excluded?"

Please use the numbers from 1 to 10 for your answer. 1 means that you feel excluded from society, 1 means that you feel integrated. With the numbers from 2 to 9 you can adjust your answer.

"I have the feeling that people around me don't recognize the value of what I do"

"Compared to others, I did not achieve what I was hoping for."

"I think that I am getting less than I deserve"

(1) definitely agree, (2) rather agree, (3) neither agree nor disagree, (4) rather disagree, (5) definitely disagree

“Generally speaking, would you say that most people can be trusted, or not?

Please tell me on a score of 1 to 10 , where 1 means you most people can't be trusted and 10 means that most people can be trusted."

\section{German (original)}

„Man kann das Gefühl haben, am gesellschaftlichen Leben teilzuhaben und dazuzugehören oder sich eher ausgeschlossen fühlen. Wie ist das bei Ihnen? Inwieweit fühlen Sie sich eher dazugehörig oder eher ausgeschlossen?"

Verwenden Sie zur Einstufung bitte die Zahlen von 1 bis 10 : 1 bedeutet, dass Sie sich vom gesellschaftlichen Leben ausgeschlossen fühlen, 10 bedeutet, dass Sie sich dazugehörig fühlen. Mit den Zahlen von 2 bis 9 können Sie Ihre Einschätzung abstufen.

„Ich habe das Gefühl, dass die Leute in meiner Umgebung den Wert meiner Tätigkeiten nicht anerkennen."

„Im Vergleich zu anderen habe ich nicht das erreicht, was ich wollte.“

„Ich denke, dass ich weniger bekomme als mir zusteht.“

(1) Stimme voll und ganz zu, (2) stimme eher zu, (3) weder/noch, (4) stimme eher nicht zu, (5) stimme überhaupt nicht zu

„Ganz allgemein gesprochen: Glauben Sie, dass man den meisten Menschen vertrauen kann, oder nicht?

Bitte sagen Sie es mir anhand einer Skala von 1 bis 10 , wobei 1 bedeutet, dass man den meisten Menschen nicht vertrauen kann und 10 bedeutet, dass man den meisten Menschen vertrauen kann.“ 
Table A. 2: Logistic Regression of AfD Voting Intention on Social Integration (Average Marginal Effects)

\begin{tabular}{|c|c|c|c|c|}
\hline & M1 & M2 & M3 & M4 \\
\hline \multicolumn{5}{|l|}{ Income (ref=low) } \\
\hline \multirow[t]{2}{*}{ middle } & -0.03 & -0.01 & -0.02 & -0.02 \\
\hline & $(0.04)$ & $(0.03)$ & $(0.03)$ & $(0.03)$ \\
\hline \multirow[t]{2}{*}{ high } & -0.04 & -0.01 & -0.02 & -0.03 \\
\hline & $(0.04)$ & $(0.04)$ & $(0.04)$ & $(0.04)$ \\
\hline \multicolumn{5}{|l|}{ Education (ref=low) } \\
\hline \multirow[t]{2}{*}{ middle } & -0.01 & 0.01 & 0.00 & -0.00 \\
\hline & $(0.03)$ & $(0.03)$ & $(0.03)$ & $(0.03)$ \\
\hline \multirow[t]{2}{*}{ high } & $-0.06^{*}$ & $-0.05^{+}$ & $-0.05^{*}$ & $-0.05^{+}$ \\
\hline & $(0.03)$ & $(0.03)$ & $(0.03)$ & $(0.03)$ \\
\hline \multicolumn{5}{|l|}{ Age (ref=18-34) } \\
\hline \multirow[t]{2}{*}{$35-49$} & -0.00 & 0.00 & 0.00 & -0.01 \\
\hline & $(0.03)$ & $(0.03)$ & $(0.03)$ & $(0.03)$ \\
\hline \multirow[t]{2}{*}{$50-64$} & 0.05 & $0.06^{+}$ & $0.06^{+}$ & 0.05 \\
\hline & $(0.04)$ & $(0.03)$ & $(0.03)$ & $(0.04)$ \\
\hline \multirow[t]{2}{*}{$65+$} & -0.03 & -0.02 & -0.02 & -0.03 \\
\hline & $(0.03)$ & $(0.02)$ & $(0.02)$ & $(0.03)$ \\
\hline \multirow[t]{2}{*}{ Female } & $-0.04+$ & -0.02 & $-0.04^{+}$ & $-0.04^{+}$ \\
\hline & $(0.02)$ & $(0.02)$ & $(0.02)$ & $(0.02)$ \\
\hline \multirow[t]{2}{*}{ Unemployed } & 0.05 & 0.02 & 0.03 & 0.04 \\
\hline & $(0.04)$ & $(0.04)$ & $(0.04)$ & $(0.04)$ \\
\hline \multirow[t]{2}{*}{ East Germany } & $0.05^{\star \star}$ & $0.05^{*}$ & $0.04^{*}$ & $0.05^{* *}$ \\
\hline & $(0.02)$ & $(0.02)$ & $(0.02)$ & $(0.02)$ \\
\hline \multirow[t]{2}{*}{ Subjective Social Exclusion } & & $0.02^{\star \star \star}$ & & \\
\hline & & $(0.01)$ & & \\
\hline \multirow[t]{2}{*}{ Status Anxiety } & & & $0.01^{*}$ & \\
\hline & & & $(0.01)$ & \\
\hline \multirow[t]{2}{*}{ Distrust } & & & & $0.01^{*}$ \\
\hline & & & & $(0.01)$ \\
\hline $\mathrm{N}$ & 917.00 & 917.00 & 917.00 & 917.00 \\
\hline
\end{tabular}

Note: Average Marginal Effects (AME) for models M1-M4 in Table A.2; standard errors in parentheses, ${ }^{+} p<0.10,{ }^{*} p<0.05,{ }^{* *} p<0.01,{ }^{\star \star *} p<0.001$ 
Table A. 3

AfD Vote Intention

Income (ref=low)

middle

$-0.01$

(0.03)

high

0.02

(0.05)

Education (ref=low)

middle

0.03

(0.02)

high

$-0.01$

(0.03)

Age (ref=18-34)

35 bis 49

$-0.01$

(0.03)

50 bis 64

$0.06^{+}$

(0.03)

$65^{+}$

$-0.02$

(0.03)

Female

$-0.03$

(0.02)

Unemployed

0.00

(0.04)

East Germany

0.03

(0.02)

Subjective Social Exclusion

$0.01^{\star *}$

(0.00)

Status Anxiety

0.00

(0.01)

Distrust

$0.01^{+}$

(0.00)

Welfare Chauvinism

$0.05^{\star \star}$

(0.02)

Pseudo-R² (McKelvey \& Zavoina)

0.60

AIC

379.697

BIC

451.733

Log Likelihood

$-174.848$

N

900.00

Note: Average Marginal Effects (AME) standard errors in parentheses, ${ }^{+} p<0.10,{ }^{*} p<0.05$, ${ }^{\star *} p<0.01,{ }^{* * *} p<0.001$ 
